\title{
Cyclosporin A in cadaveric organ transplantation
}

\author{
R Y CALNE, D J G WHITE, D B EVANS, S THIRU, R G HENDERSON, D V HAMILTON, \\ K ROLLES, P MCMASTER, T J DUFFY, B R D MACDOUGALL, R WILLIAMS
}

\begin{abstract}
The use of cyclosporin A (CyA) with a protocol designed to avoid the effects of nephrotoxicity resulted in a oneyear survival of $86 \%$ in recipients of renal allografts from unmatched cadaveric donors. The drug also controlled rejection of liver and pancreatic allografts. It was possible to change patients initially treated with CyA to azathioprine and corticosteroids and vice versa, thus enlarging the potential value of CyA in organ allografting. Of 34 recipients of renal allografts, 29 were currently receiving only $\mathrm{CyA}$ as immunosuppressive treatment. Twelve patients never required any adjuvant steroid treatment.
\end{abstract}

These results suggest that $\mathrm{Cy} A$ is an effective immunosuppressant, and if used with care side effects need not be severe.

\section{Introduction}

In a pilot study of cyclosporin $\mathrm{A}(\mathrm{CyA})$ in organ transplantation we found the agent to be an extremely powerful immunosuppressant which may be effective without corticosteroids in renal, pancreatic, and hepatic allografting. ${ }^{1-3} \mathrm{CyA}$ given to 15 patients with oliguria, however, further impaired renal function, so that additional corticosteroids and "cytimun" (a cyclophosphamide analogue) were given in the mistaken belief that this was a manifestation of rejection, though histological changes did not indicate severe immune reactions. The result was excessive immunosuppression, a high incidence of bacterial, viral, and fungal infection, and the development of three lymphomas. When CyA dosage was reduced below $3 \mathrm{mg} / \mathrm{kg}$ in two patients ${ }^{4}$ severe allograft rejection developed, rapidly controlled by stopping CyA and substituting azathioprine and prednisolone.

We therefore developed a protocol in which CyA was given only to patients with primary functioning kidneys. Administration of fluid and diuretics during operation lowered the incidence of primary oliguria and nephrotoxicity. The use of additional corticosteroids was limited, and if rejection was not quickly controlled CyA was stopped and immunosuppression continued with azathioprine and prednisolone. We also changed patients treated with azathioprine and corticosteroids to CyA in order to alleviate the side effects of corticosteroids.

\footnotetext{
University of Cambridge, Addenbrooke's Hospital, Cambridge CB2 2QQ

R Y CALNE, MS, FRCS, FRS, professor of surgery

D J G WHITE, BSC, PHD, research associate

D B EVANS, MD, FRCP, consultant nephrologist

S THIRU, MB, MRCP, consultant pathologist

R G HENDERSON, MD, MRCP, consultant physician

D V HAMILTON, MA, MRCP, senior registrar

$\mathrm{K}$ ROLLES, BSC, FRCS, lecturer in surgery

$T$ J DUFFY, MA, FRCs, lecturer in surgery

Queen Elizabeth Hospital, Birmingham B15 2TH

P MCMASTER, CHM, FRCS, consultant surgeon

King's College Hospital, London SE5 9RS

B R D MACDOUGALL, MB, MRCP, senior registrar

R WILLIAMS, MD, FRCP, director of liver unit
}

We report our experience with renal allograft recipients managed by the new hydration protocol, with patients whose immunosuppression was changed from or to $\mathrm{CyA}$, and with patients with segmental pancreatic allografts treated with CyA.

\section{Patients and methods}

Group 1. Patients with kidney grafts given $C y A$ as initial sole immunosuppressive agent-Thirty-nine patients received cadaveric allografts. Their ages ranged from 2 to 68 years, $13(33 \%)$ being over 50. Thirty-seven of the operations were for first grafts and two were for second, the first graft having failed to technical reasons. All patients received organs mismatched for HLA-A and B locus antigens; in most there were two or more mismatches. Details of DR matching were not available. Thirty-eight patients had had blood transfusions. Hydration began just before operation and continued in the postoperative phase, care being taken not to overload the circulation; in most cases the central venous pressure was measured. Six hours after operation, and provided that urine output was $100 \mathrm{ml} /$ hour or greater, the patient began CyA, $17 \mathrm{mg} / \mathrm{kg}$ intramuscularly. As soon as fluids could be taken by mouth, usually on the second day, CyA was given as a drinking emulsion mixed with fruit juice or chocolate. After one month the dose was reduced by $2 \mathrm{mg} / \mathrm{kg}$ daily, and similar stepwise reductions were made every month until a maintenance dose of 6-8 $\mathrm{mg} / \mathrm{kg}$ was reached. Allografts with deteriorating function were subjected to biopsy. Histological evidence of rejection was treated with three $1 \mathrm{~g}$ doses of intravenous methylprednisolone (SoluMedrone) on consecutive days, and if improvement had not resulted during the next week the treatment was repeated. If function did not improve CyA was stopped and treatment changed to azathioprine and corticosteroids in conventional doses. If biopsy showed no rejection CyA was reduced by $30 \%$.

Group 2. Patients with liver or kidney grafts initially treated with or changed to $C y A-$ Many patients selected for liver grafting have impaired renal function, and renal failure is a common complication of operation. We used $\mathrm{CyA}$ as the initial immunosuppressive agent in seven patients receiving orthotopic liver grafts. A new protocol was used in $\mathbf{1 0}$ patients with liver allografts, in two patients who did not have a primary diuresis after renal transplantation, and in two others initially treated with other drugs. Patients were initially treated with a standard regimen of azathioprine and corticosteroids. If there was no evidence of rejection, treatment was changed to CyA $10 \mathrm{mg} / \mathrm{kg} / \mathrm{day}$ after the 14th day, provided that the serum creatinine concentration was below $150 \mu \mathrm{mol} / \mathrm{l}(1.7 \mathrm{mg} / 100 \mathrm{ml})$. If rejection was confirmed by biopsy while a patient was taking azathioprine and corticosteroids, the prednisolone dose was raised to $3 \mathrm{mg} / \mathrm{kg}$ and then reduced by 0.5 $\mathrm{mg} / \mathrm{kg}$ every three days. When both hepatic and renal function were stable and the dose of prednisolone was $1 \mathrm{mg} / \mathrm{kg}$ or less, CyA was started, azathioprine stopped, and prednisolone reduced as rapidly as possible.

Group 3. Patients given segmental pancreatic allografts for insulin dependent diabetes-Nine patients were treated with CyA as the sole initial drug. Seven received simultaneous transplantation of rena allografts from the same donor, and one a liver allograft from the same donor. The ninth patient with progressive blindness received only a pancreatic allograft. One patient developed rejection of the kidney that could not be controlled by $\mathrm{CyA}$ and was changed to azathioprine and corticosteroids.

\section{Results}

Group 1-Of the 39 kidney allograft recipients treated with CyA, two died from sepsis and one from haemorrhage after renal biopsy (figure). Two allografts were removed, one for local wound sepsis and the other for uncontrollable rejection. The remaining 34 grafts continued to function for two years to two months, 12 without the 
need for additional corticosteroids. Seventeen patients were treated with corticosteroids for rejection episodes, but these drugs were later stopped, so that 29 of the 34 patients were no longer taking them; five patients were converted to azathioprine and corticosteroids with satisfactory control of rejection and good function in the transplants.

Group 2-Five of the seven patients initially treated with CyA had functioning liver allografts at 6-13 months (table I). One died at three weeks in acute heart failure, and two developed severe renal failure requiring dialysis. CyA was stopped: one patient rejected the liver

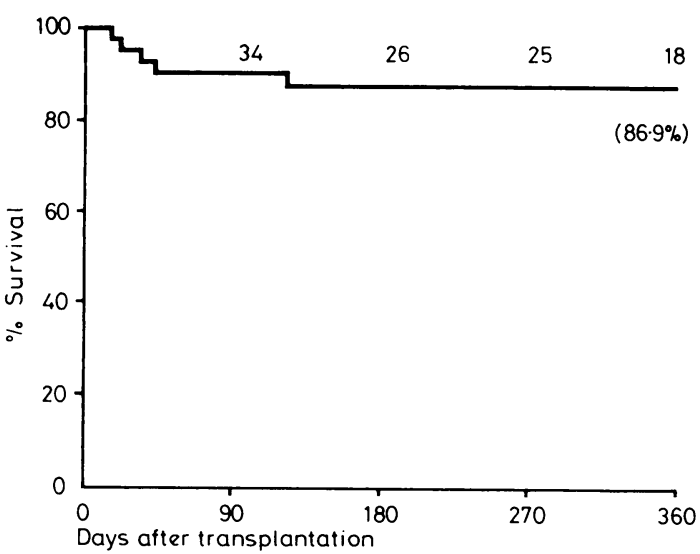

Actuarial survival of 39 cadaveric kidney allograft recipients immunosuppressed with cyclosporin A. Figures on plot are actual numbers of survivors. (Calculated by method of Kaplan and Meier. ${ }^{2}$ ) and died; the other was given azathioprine and corticosteroids and was changed back to CyA when renal function recovered. Three liver and two kidney graft recipients were converted to CyA as a deliberate policy as soon as allograft function was stable. Seven patients with liver transplants and two with kidney transplants were converted to CyA between three months and three years after operation. One of the patients with a renal allograft was started on CyA, cytimun, and prednisolone and continued with CyA alone. The other, given three months' treatment with azathioprine and prednisolone, developed bilateral hip arthritis requiring six weeks of traction. He was last being treated with $\mathrm{CyA}$; azathioprine had been stopped and prednisolone was being slowly withdrawn. After conversion, allograft function continued with little change in all cases.

Group 3-Of the nine patients given segmental pancreatic allografts, two died, one on the fourth day from overhydration causing acute cardiac failure, and the other from septicaemia (table II). Two patients had their allografts removed for rejection; in both cases rejection was first observed clinically by deteriorating renal function, and peripancreatic sepsis occurred, with leakage of exocrine secretion. One of these patients was given a second kidney transplant and treated with azathioprine and corticosteroids; the other received dialysis. Both were taking insulin. A further patient developed uncontrollable rejection of the kidney 70 days after operation, and immunosuppression was changed to azathioprine and corticosteroids. Renal function was restored but the use of corticosteroids necessitated the reintroduction of insulin. The remaining four pancreatic allografts were functioning. The patients did not require insulin or corticosteroids, two (one with a kidney transplant, and one with a liver transplant) after more than a year, one at six months with a kidney transplant, and one at three months without any other organ graft. Renal function deteriorated in the last patient after pancreatic grafting and he required dialysis, but results of renal function tests returned to preoperative values after a reduction in CyA dosage.

TABLE I-Details of 14 patients converted to cyclosporin $A(C y A)$

\begin{tabular}{|c|c|c|c|c|c|c|c|c|c|}
\hline \multirow{2}{*}{$\begin{array}{l}\text { Case } \\
\text { No }\end{array}$} & \multirow{2}{*}{\multicolumn{2}{|c|}{$\begin{array}{l}\text { Age and } \\
\text { sex }\end{array}$}} & \multirow{2}{*}{$\begin{array}{l}\text { Reason for transplantation, } \\
\text { and organ transplanted }\end{array}$} & \multirow{2}{*}{$\begin{array}{l}\text { Days after } \\
\text { operation of } \\
\text { conversion } \\
\text { to CyA }\end{array}$} & \multirow{2}{*}{$\begin{array}{c}\text { Current } \\
\text { graft } \\
\text { survival } \\
\text { (days) }\end{array}$} & \multicolumn{3}{|c|}{$\begin{array}{l}\text { Current graft function } \\
\text { (serum concentrations) }\end{array}$} & \multirow{2}{*}{$\begin{array}{l}\text { Prednisolone dose } \\
\text { (mg/day) }\end{array}$} \\
\hline & & & & & & $\begin{array}{l}\text { Bilirubin } \\
(\mu \mathrm{mol} / \mathrm{l})\end{array}$ & $\underset{(\mathrm{mmol} / \mathrm{l})}{\text { Urea }}$ & $\underset{(\mu \mathrm{mol} / \mathrm{l})}{\text { Creatinine }}$ & \\
\hline $\begin{array}{l}1^{*} \\
2^{*} \\
3^{*} \\
4^{*} \\
5^{*} \\
6 \\
7 \\
8 \\
9 \\
10 \\
11 \\
12 \\
13 \\
14\end{array}$ & $\begin{array}{l}47 \\
29 \\
42 \\
19 \\
40 \\
24 \\
55 \\
52 \\
59 \\
27 \\
49 \\
37 \\
43 \\
35\end{array}$ & $\begin{array}{l}M \\
\mathrm{~F} \\
\mathrm{~F} \\
\mathrm{~F} \\
\mathrm{M} \\
\mathrm{F} \\
\mathrm{M} \\
\mathrm{F} \\
\mathrm{M} \\
\mathrm{F} \\
\mathrm{F} \\
\mathrm{M} \\
\mathrm{M} \\
\mathrm{M}\end{array}$ & $\begin{array}{l}\text { Sclerosing cholangitis. Liver } \\
\text { Cholangiocarcinoma. Liver } \\
\text { Primary biliary cirrhosis. Liver } \\
\text { Pyelonephritis. Kidney } \\
\text { Chronic renal failure ?cause. Kidney } \\
\text { Budd-Chiari. Liver } \\
\text { Primary biliary cirrhosis. Liver } \\
\text { Primary biliary cirrhosis. Liver } \\
\text { Primary biliary cirrhosis. Liver } \\
\text { Chronic active hepatitis. Liver } \\
\text { Polycystic kidney. Kidney } \\
\text { Glomerulonephritis. Kidney } \\
\text { Secondary biliary cirrhosis. Liver } \\
\text { Hepatoma. Liver }\end{array}$ & $\begin{array}{r}30 \\
31 \\
47 \\
25 \\
25 \\
132 \\
1372 \\
1295 \\
968 \\
493 \\
0 \\
88 \\
1434 \\
1748\end{array}$ & $\begin{array}{r}158 \\
81 \\
73 \\
49 \\
42 \\
205 \\
1441 \\
1332 \\
1052 \\
529 \\
756 \\
170 \\
1451 \\
1765\end{array}$ & $\begin{array}{r}20 \\
26 \\
150 \\
21 \\
13 \\
19 \\
100 \\
40 \\
19 \\
12 \\
10 \\
12 \\
26 \\
12\end{array}$ & $\begin{array}{r}14.4 \\
5.0 \\
4.5 \\
31 \cdot 6 \\
14 \cdot 4 \\
5.9 \\
11.7 \\
6.0 \\
11.6 \\
4.0 \\
11.1 \\
12 \cdot 2 \\
7.3 \\
8.6\end{array}$ & $\begin{array}{r}166 \\
60 \\
48 \\
304 \\
192 \\
61 \\
132 \\
96 \\
266 \\
78 \\
147 \\
304 \\
100 \\
87\end{array}$ & $\begin{array}{l}\text { 0. Stopped } 6 / 7 / 80,11 \text { days after starting CyA } \\
12 \cdot 5 \\
30 \\
12 \cdot 5 \\
30 \\
8 \\
15 \\
7 \\
0 \\
5 \\
0 \text { from } 11 / 2 / 79 \\
0 \text { from } 20 / 9 / 80,41 \text { days after starting CyA } \\
7 \\
6\end{array}$ \\
\hline
\end{tabular}

*Cases 1-5, new protocol: starting with azathioprine and prednisolone; changing to CyA when allograft function stable.

Conversion: SI to traditional units-Bilirubin: $1 \mu \mathrm{mol} / 1 \approx 0.06 \mathrm{mg} / 100 \mathrm{ml}$. Urea: $1 \mathrm{mmol} / 1 \approx 6 \mathrm{mg} / 100 \mathrm{ml}$. Creatinine: $1 \mu \mathrm{mol} / 1 \approx 0.01 \mathrm{mg} / 100 \mathrm{ml}$.

TABLE II-Details of nine patients with segmental pancreatic grafts

\begin{tabular}{|c|c|c|c|c|c|c|c|c|c|c|}
\hline \multirow{3}{*}{$\begin{array}{l}\text { Case } \\
\text { No }\end{array}$} & \multirow{2}{*}{\multicolumn{2}{|c|}{$\begin{array}{l}\text { Age and } \\
\text { sex }\end{array}$}} & \multirow{3}{*}{$\begin{array}{c}\begin{array}{c}\text { Other organ } \\
\text { grafted }\end{array} \\
\begin{array}{l}\text { Kidney } \\
\text { Liver } \\
\text { Kidney }\end{array}\end{array}$} & \multirow{3}{*}{$\begin{array}{c}\begin{array}{c}\text { Days of } \\
\text { pancreatic } \\
\text { graft } \\
\text { survival }\end{array} \\
>439 \\
>394 \\
3\end{array}$} & \multicolumn{4}{|c|}{ Graft function (serum concentrations) } & \multirow{2}{*}{$\begin{array}{l}\text { Insulin } \\
\text { requirement }\end{array}$} & \multirow{2}{*}{ Observations } \\
\hline & & & & & $\underset{(\mu \mathrm{mol} / \mathrm{l})}{\text { Bilirubin }}$ & $\underset{(\mathrm{mmol} / \mathrm{l})}{\text { Urea }}$ & $\begin{array}{c}\text { Creatinine } \\
(\mu \mathrm{mol} / 1)\end{array}$ & $\begin{array}{c}\text { Glucose } \\
(\mathrm{mmol} / \mathrm{l})\end{array}$ & & \\
\hline & $\begin{array}{l}55 \\
25 \\
47\end{array}$ & $\begin{array}{l}\mathrm{F} \\
\mathbf{F}\end{array}$ & & & $\begin{array}{l}15 \\
40 \\
-\end{array}$ & $\begin{array}{l}11 \cdot 7 \\
20 \cdot 0 \\
-\end{array}$ & $\begin{array}{l}155 \\
266 \\
-\end{array}$ & $\begin{array}{l}5 \cdot 9 \\
4 \cdot 3 \\
-\end{array}$ & $\begin{array}{l}0 \\
0 \\
-\end{array}$ & $\begin{array}{l}\text { Treated with CyA* only } \\
\text { Was on prednisolone for hepatitis. Stopped on day } 254 \\
\text { Died on day } 3 \text { from acute congestive cardiac failure due to } \\
\text { fluid overload }\end{array}$ \\
\hline 18 & 43 & $\mathbf{M}$ & Kidney & 11 & - & - & - & - & - & $\begin{array}{l}\text { Rejected kidney and pancreas. Pancreas removed 5/11/79. } \\
\text { 2nd renal allograft 29/12/79. On azathioprine and } \\
\text { prednisolone }\end{array}$ \\
\hline 19 & 37 & $\mathbf{M}$ & Kidney & $>250$ & 12 & $9 \cdot 0$ & 188 & $7 \cdot 5$ & $\mathbf{0}$ & $\begin{array}{l}\text { Rejection of both grafts reversed with course of } \\
\text { methylprednisolone }\end{array}$ \\
\hline 20 & $\begin{array}{l}32 \\
38\end{array}$ & $\underset{\mathbf{F}}{\mathbf{M}}$ & $\begin{array}{l}\text { Kidney } \\
\text { Kidney }\end{array}$ & $\begin{array}{r}71 \\
>186\end{array}$ & $\overline{6}$ & $\overline{18 \cdot 9}$ & $\overrightarrow{208}$ & $\overline{3 \cdot 3}$ & $\begin{array}{l}16 \overline{\text { units }} \\
\text { twice daily }\end{array}$ & $\begin{array}{l}\text { Died on day } 71 \text { of sepsis after rejection of both grafts } \\
\text { Persistent rejection failed to respond to course of } \\
\text { methylprednisolone. CyA stopped on day } 125 \text {. } \\
\text { Azathioprine } 50 \mathrm{mg} \text {, prednisolone } 30 \mathrm{mg}\end{array}$ \\
\hline 22 & 36 & $\mathbf{M}$ & None & $>131$ & 68 & $27 \cdot 0$ & 278 & $3 \cdot 8$ & 0 & $\begin{array}{l}\text { Renal failure after pancreas grafting. Required dialysis. } \\
\text { Return to preoperative renal function }\end{array}$ \\
\hline 23 & 45 & $\mathbf{M}$ & Kidney & 50 & - & - & 一 & - & - & $\begin{array}{l}\text { Rejected kidney despite methylprednisolone course. } \\
\text { Peripancreatic sepsis with exocrine fistula. Both grafts } \\
\text { removed on day } 50 \text {. On dialysis }\end{array}$ \\
\hline
\end{tabular}

* Cyclosporin A. Conversion:
$\mathrm{mg} / 100 \mathrm{ml}$. 


\section{Discussion}

With this protocol the results obtained with CyA in patients given cadaveric renal allografts were very much better than we had obtained before. Though selected for primary function (but not immunologically), these patients (one-third of whom were over 50 ) have an $86 \%$ predicted graft survival at one year, which is unusual. They included five patients in whom CyA did not control rejection and who were changed satisfactorily to azathioprine and corticosteroids.

Starzl et al suggested that corticosteroids should be used routinely in addition to CyA. ${ }^{5}$ Since three-quarters of our patients with functioning renal allografts were receiving CyA only and nearly a third had never been treated with corticosteroids, we think that patients should be given the chance to avoid the latter drugs. Early experience with continuous administration of corticosteroids with $\mathrm{CyA}^{2}$ was associated with a high incidence of infectious complications and lymphomas. With the new protocol there were no new cases of lymphoma, and probably the development of such tumours is not specifically related to CyA but to excessive and inappropriate immunosuppression.

Nephrotoxicity has been the most serious complication of CyA. Other side effects have been growth of soft, downy facial and body hair, gum hypertrophy, tremor, mild hepatotoxicity (usually manifested by slight derangement of liver function values), and subclinical marrow depression. Two cases of benign mammary fibroadenomas have occurred. ${ }^{4}$

Though we and Starzl $e t a l^{35}$ have reported good results using CyA as an initial immunosuppressive drug in liver allografts, two of our patients developed renal failure which may have been aggravated by CyA, and we now start CyA only when the patient is stable. Initial results have been satisfactory and we have extended this regimen to patients excluded from initial immunosuppression with CyA for renal allografts because of primary oliguria. We have also converted to CyA transplant recipients who have developed side effects from corticosteroids; follow-up is short, but it is already clear that hepatic and renal function can be satisfactorily maintained.

Transplantation of the pancreas has been undertaken because of the powerful immunosuppressive effect of $\mathrm{CyA}$, which can in some cases control rejection without the need for corticosteroids. Attempts to prevent exocrine secretion by injecting latex into the pancreatic duct $^{6} 7$ have not always been successful, and infection is likely to be aggravated because latex is a foreign body. We propose in future to inject the ducts with Ethibloc, a polymerised amino-acid, which is broken down in the body. ${ }^{8}$

The future of segmental pancreatic allografting depends on whether control of diabetes can prevent progression of microangiopathy and therefore deterioration of vision and renal function. It would then be an attractive treatment for certain patients with complicated diabetes.

CyA is effective in clinical organ and marrow allografting.9 The limited information on its pharmacokinetics ( $M$ Lemaire and G Gsell; G Maurer and E Schreier; and T Beveridge et al -all unpublished) makes it difficult to use in practice. Control of rejection and prevention of nephrotoxicity can be achieved by monitoring blood concentrations using a radioimmunoassay and modifying the dose to maintain a trough concentration of 200-400 $\mu \mathrm{g} / \mathrm{l}^{10}$ Unlike the oral preparation, CyA administered intramuscularly fails to provide significant $(<50 \mu \mathrm{g} / \mathrm{l})$ blood concentrations as measured by radioimmunoassay, but more data are required before drawing conclusions on the clinical relevance of blood values.

We were surprised how often renal allograft rejection not controlled by $\mathrm{CyA}$ responded to azathioprine and prednisolone.
This may have been due to different mechanisms of action or to variation in absorption or metabolism of CyA in different patients. Patients experiencing side effects with corticosteroids have responded well to CyA. Patients receiving CyA should not be given prolonged courses of corticosteroids or other immunosuppressive agents because of the danger of excessive damage to the immune system, with the attendant risks of infection and lymphoma induction. Thus we find that patients treated with CyA alone are capable of producing a more vigorous humoral response, as assessed by immunoglobulin concentrations, than are those treated with CyA and corticosteroids or conventional immunosuppressive agents. ${ }^{11}$

The ease with which patients may be changed to and from CyA provides a valuable alternative immunosuppressive tool. As maintenance treatment CyA is usually preferable, since corticosteroids can be avoided. Serum creatinine concentrations, however, are higher $(208 \mu \mathrm{mol} / 1(2.4 \mathrm{mg} / 100 \mathrm{ml})$ at six months) than with conventional drugs $(114 \mu \mathrm{mol} / 1(1.3 \mathrm{mg} / 100 \mathrm{ml})$ at $\mathrm{six}$ months). When patients are changed to azathioprine and prednisolone, serum creatinine concentrations usually fall rapidly, but such changes have been necessitated by poor control of rejection, and improvement in renal function may be due to recovery from rejection as well as to stopping the nephrotoxic CyA. Change to CyA in the absence of rejection is usually followed by a rise in serum creatinine concentrations, which tend to peak and then fall to remain moderately raised.

Our results are encouraging, and a randomised multicentre trial is now planned to compare $\mathrm{CyA}$ with conventional azathioprine and corticosteroids in recipients of cadaveric renal allografts.

We are grateful to Sandoz Ltd for their help and to our medical, scientific, nursing, and technical colleagues at Cambridge and the Liver Unit, King's College Hospital, London.

\section{References}

${ }^{1}$ Calne RY, White DJG, Thiru S, et al. Cyclosporin A in patients receiving renal allografts from cadaver donors. Lancet 1978;ii:1323-7.

2 Calne RY, Rolles K, White DJG, et al. Cyclosporin A initially as the only immunosuppressant in 34 recipients of cadaveric organs: 32 kidneys, 2 pancreases, and 2 livers. Lancet 1979;ii:1033-6.

${ }^{3}$ Calne RY, Rolles K, White DJG, et al. Cyclosporin A in clinical organ grafting. Transplant Proc (in press).

4 Rolles K, Calne RY. Two cases of benign lumps after treatment with cyclosporin A. Lancet 1980;ii:795.

5 Starzl TE, Weil R III, Iwatsuki S, et al. The use of cyclosporin A and prednisone in cadaver kidney transplantation. Surg Gynecol Obstet $1980 ; 151: 17-26$.

- Dubernard JM, Traeger J, Neyra P, et al. A new method of preparation of segmental pancreatic grafts for transplantation: trials in dogs and in man. Surgery 1978;84:633-9.

${ }^{7}$ McMaster P, Procyshyn A, Calne RY, Valdes R, Rolles K, Smith DJ. Prolongation of canine pancreas allograft survival with cyclosporin A: preliminary report. $\mathrm{Br} \mathrm{Med} \mathcal{f} 1980 ; 280: 444-5$

8 Land W, Weitz H. Prolamine solution to block pancreatic duct. Lancet 1979 ;ii:1131.

9 Powles RL, Clink HM, Spence D, et al. Cyclosporin A to prevent graftversus-host disease in man after allogeneic bone-marrow transplantation. Lancet 1980;i:327-9.

10 Keown PA, Stiller CR, Sinclair NR, Ulan RA, Howson WT, Lockie C. Suppression of the donor specific immune response by cyclosporin $\mathrm{A}$ following renal transplantation. Transplant Proc (in press).

11 White DJG, Plumb A, Calne RY. The immune status of transplant recipients immunosuppressed with cyclosporin A. Transplant Proc (in press).

12 Kaplan EL, Meier P. Nonparametric estimation from incomplete observations. American Statistical Association fournal 1958;53:457.

(Accepted 12 Fanuary 1981) 